\title{
Dispersion of Pollutants from Line Sources in Small Municipalities
}

\author{
J. Pospíšil* \\ Brno University of Technology \\ *Corresponding author: pospisil.j@fme.vutbr.cz \\ J. Huzlík, R. Ličbinský \\ Transport Research Centre, Brno
}

DOI: $10.2478 /$ trans-2014-0014

\begin{abstract}
The article deals with the issue of dispersion and spreading of pollutants in small municipalities. The main attention is paid to the spreading of pollutants from line sources, i.e. roads in this case. Numerical modelling for selected localities, complemented with local measurements, is used for finding relations of dispersion of pollutants. The impact of a specific layout of urban areas on the dispersion of pollutants is monitored. Line sources, representing roads in numerical models, are described by the productions of pollutants and corresponding aerodynamic effects of moving vehicles on the ambient air. A large number of concentration maps are converted into a comprehensive database which allows a fast evaluation of similar situations without new immediate solutions or demanding SW tools.
\end{abstract}

KEY WORDS: Dispersion modelling, particulate matter, small cities.

\section{INTRODUCTION}

The outcomes presented in this article are a partial outcome of a project "Kvantifikace znečištění ovzduší a z něj vyplývajících zdravotních rizik v malých sídlech České Republiky a systém řízení" (Quantification of air pollution and the resulting health risks in small settlements of Czech Republic and system solutions). The project focuses on creating an operative system that evaluates the exposure of local population to imissions in small settlements. A catalogue of concentration maps of selected model areas of small settlements was designed as a suitable approach allowing for a fast evaluation. This article focuses on imissions from road traffic.

When selecting a suitable model tool for detail calculation of pollutants in small settlements, a CFD (computational flow dynamics) modelling method was chosen. This method allows to calculate complex 3D concentration fields of pollutants on the basis of the real geometry. 


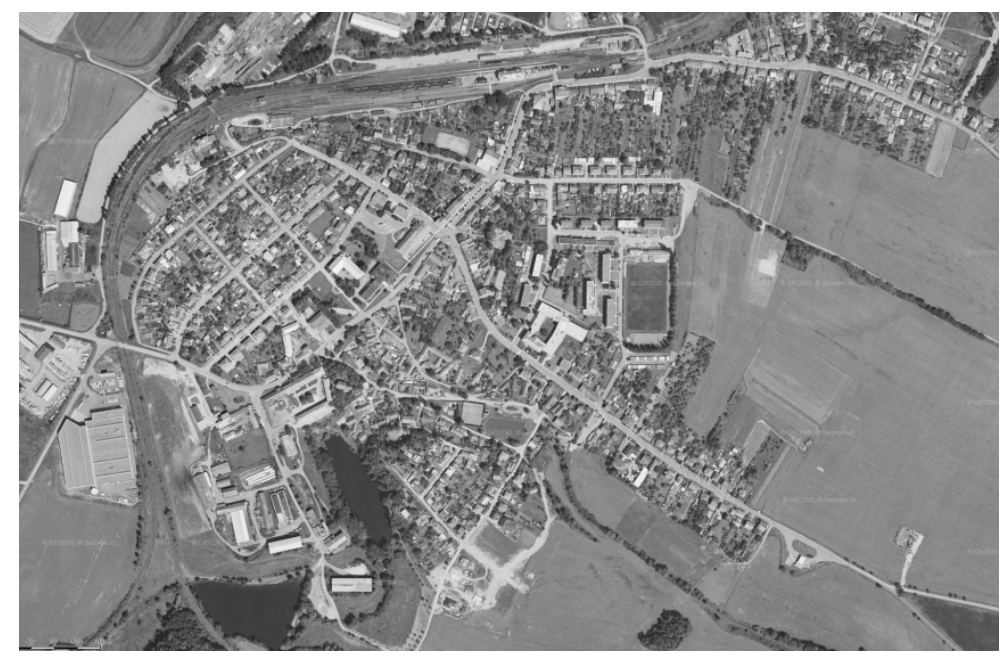

Figure 1: Illustrative example of a small settlement Okř́šky, aerial view.

\section{CLASSIFICATION STRATEGY OF MODEL AREAS OF SMALL SETTLEMENTS}

The selection of model areas of small settlements was performed with the aim to prepare numerical models of selected areas which represent characteristic configurations of buildings and emission sources in small settlements in terms of spreading of pollutants. The selected model areas are used for calculating concentration maps of imission levels. The obtained results should be representative and usable for evaluations of a large number of small settlements of a similar layout.

In the first step when selecting model areas, the attention was paid to the character of urban layout in relation to the main road. Small settlements were classified as follows in this step:

- bordering a transit road,

- run through by a transit road.

An extensive study of aerial views of small settlements helped us to select two characteristic shapes of transit roads which frequently appear in small settlements:

- direct road,

- road with a change in direction by $90^{\circ}$.

Another feature of the selected model areas was the shape of built-in areas. In this respect, the characteristic model areas of small settlements were divided into three groups:

- solitary standing family houses forming a settlement,

- continuous row of buildings surrounding the main road and other solitary structures,

- urban character of a small settlement with street canyons in its central part.

\section{MODEL OF POLLUTANT DISPERSION AND RELATED BOUNDARY CONDITIONS}

CFD (computational flow dynamics) method was used for the creation of concentration maps of pollutants. This method allows to include a detailed description of the geometry of an area and the dispersion of pollutants on computed 3D air velocity field. Euler method was used as a suitable approach to deal with the pollutant dispersion. This method is based on a numerical approach to the system of differential equations accurately describing air flow and transport of gaseous pollutants and small suspended particles. The solution can be stationary as well as nonstationary. The correctness of the calculated air velocity field depends on the quality 
of the assigned geometry of an area and assigned boundary conditions. In this case, there is no fundamental limitation, thus when dealing with urban areas the calculation can include detailed geometry of individual buildings. The information on the concentration of pollutants is collected in nodal points of the model network on the basis of balance equations for conservation of matter, energy and momentum, which describe the transfer between individual volume elements of the numerical model. The size reduction of the used volume elements increases the accuracy of results but significantly increases the difficulty of the calculation. This fact requires a careful decision of the size of the area in question and of the size of the used volume elements.

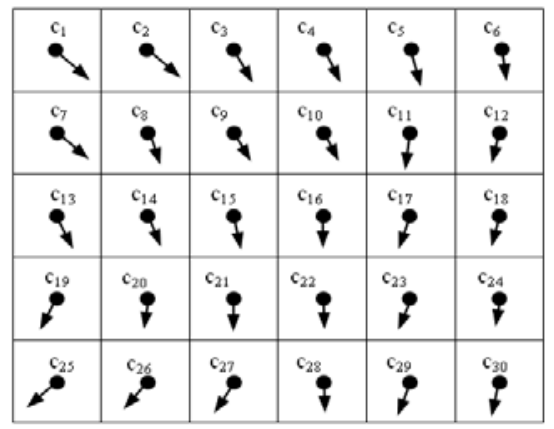

Figure 2: Outlining the description by Euler method - calculation of concentrations are known in the centres of selected control volumes.

The dispersion of pollutants is critically influenced by the existing air velocity field. The air field in a given area is formed by the effects of the assigned wind, geometry of buildings, and the effect of moving vehicles near roads. The impact of vehicles is crucial in most cases when dealing with the area above the road and in close vicinity to the road. The movement of vehicles is crucial for the speed of spreading pollutants, particularly in situations when the natural advection is insufficient (e.g. in windless conditions). The inclusion of moving vehicles in the calculation is performed in two steps:

- inclusion of force effects of vehicle on air,

- inclusion of production of the kinetic energy of turbulence.

The force effects of the air on moving vehicles are described by the resistance force

$$
\vec{F}_{D}=\frac{1}{2} \rho C_{D} A_{p}\left|\vec{U}_{\infty}-\vec{U}_{c a r}\right|\left(\vec{U}_{\infty}-\vec{U}_{c a r}\right),
$$

where $\rho \ldots$ air density,

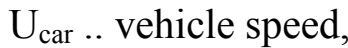

$\mathrm{U}_{\infty} \ldots$ air velocity in the place of the moving vehicle,

$\mathrm{Q}_{\mathrm{car}} \ldots$ traffic volume,

$\mathrm{C}_{\mathrm{D}} \ldots$ aerodynamic resistance constant.

The reaction to the aerodynamic resistance force is the force that the vehicle pushes the fluid. This effect is included in the calculation in the form of the volume force active at places where vehicles drive through, see Figure 3. 


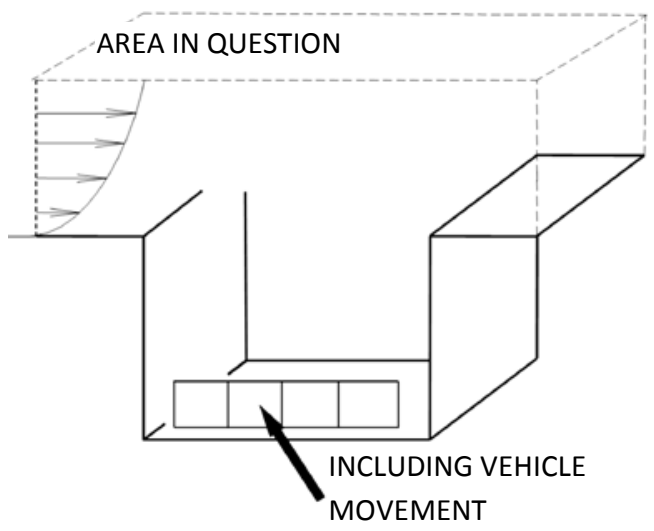

Figure 3: Example of inclusion of moving vehicle impact on a four-lane road enclosed by buildings from both sides.

The created detailed mathematical model always represents only a part of the real area. The size of the model itself is limited by the amount of time for processing and by the used hardware. The limitations due to the limited model size lead to the use of corresponding boundary conditions which accurately substitute the influence of the surroundings. The boundary condition "slip wall" is used for the upper border of the area in question. The boundary conditions assigned to walls must allow prescribing the velocity profile above the terrain corresponding with real conditions in the lower atmospheric level. This approach allows to include the effect of the surrounding environment at the place of the area border. The mathematical expression of the wind velocity profile is

$$
u=u_{r e f}\left(\frac{z}{z_{r e f}}\right)^{a}
$$

where, $\quad u$... wind velocity in height $\mathrm{z}$,

$\mathrm{u}_{\mathrm{ref}} \ldots$ wind velocity in reference height,

$\mathrm{z}$... elevation coordinate,

$Z_{\text {ref }}$... referential height,

a ... velocity profile coefficient.

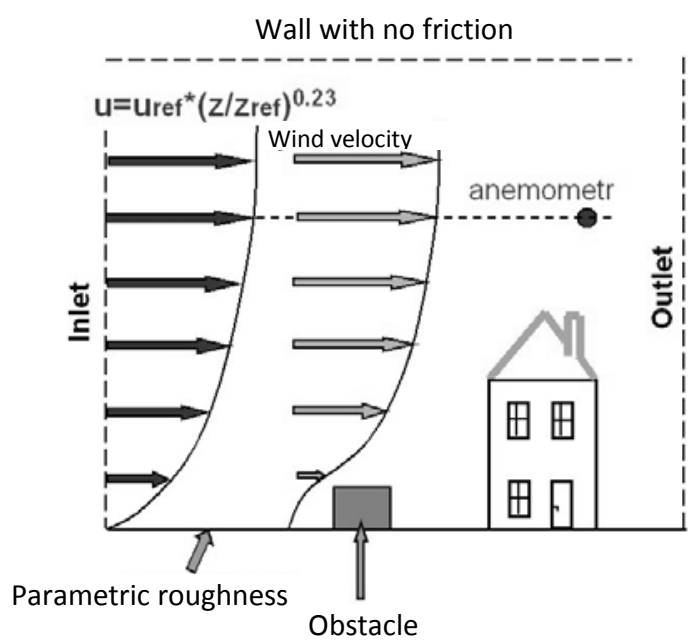

Figure 4: Assigned wind at the edge of area in question with the use of "velocity profile". 
The air mass in the model moves above the terrain described by the corresponding parametric roughness. The terrain has an impact on the original velocity profile in relation to specific local conditions, see Figure 4.

\section{EXAMPLE OF REACHED RESULTS}

In order to calculate concentration maps, an area of $2000 \times 2000 \mathrm{~m}$ with a village of Okrrišky was processed into a numerical model, see Figure 5.

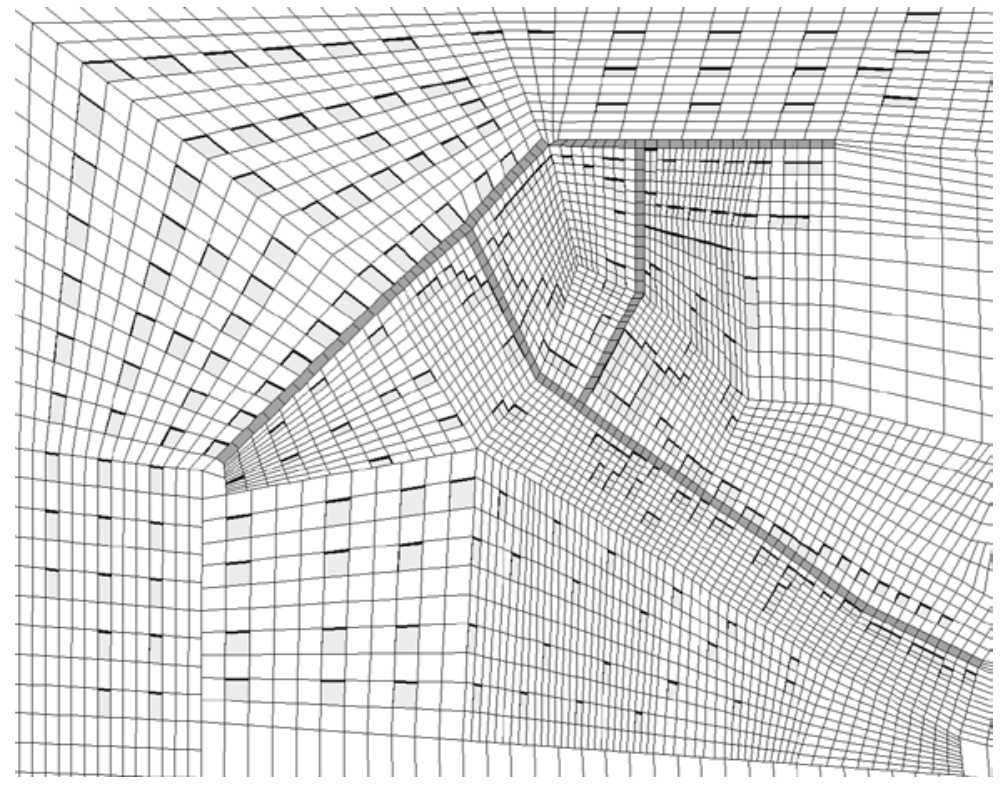

Figure 5: Road and buildings in created numerical network - top view.

The considered line sources representing important roads were described by traffic volume and the corresponding emission factor. In the model area the line emission sources of corresponding roads running through streets of Masarykova, Nádražní and Jihlavská were assigned. The line sources were included in the model along the length of the monitored roads in the village. These roads were assigned with the parameters of the production of monitored pollutants.

The solution includes the advective and diffusion method of pollutant transfer in the calculated air flow field. The diffusion is considered both molecular diffusion and turbulent diffusion due to effect of the complex whirlwind structure of the flow. The used simplified solution is based on neglecting deposition mechanisms (with the exclusion of PM10), whose manifestation is very limited on short distances. The solution was performed with zero concentration of the background. The results show the contribution of line sources to the total imission concentration in the area.

An example of calculated concentration fields of the specific emission for the model area Okříšky is shown in Figure 6 and Figure 7. The expressed imission burden is shown in the form of a specific imission, which provides the qualitative overview on shapes of concentration fields. We can obtain the real pollutant concentration by multiplying the specific imissions with the ratio of the real and specific emissions produced by vehicles on the road. 


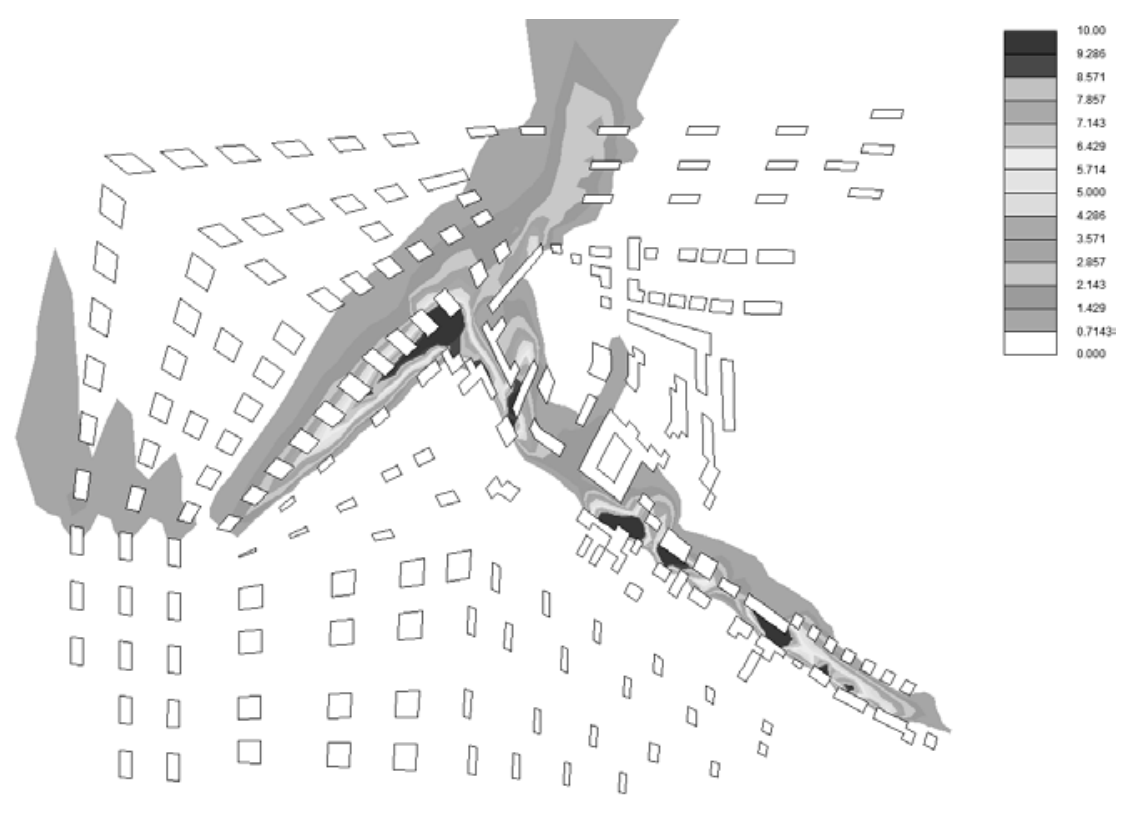

Figure 6: Calculated concentration field of specific emissions for south wind of $\mathbf{2} \mathbf{~ m} / \mathbf{s}$.

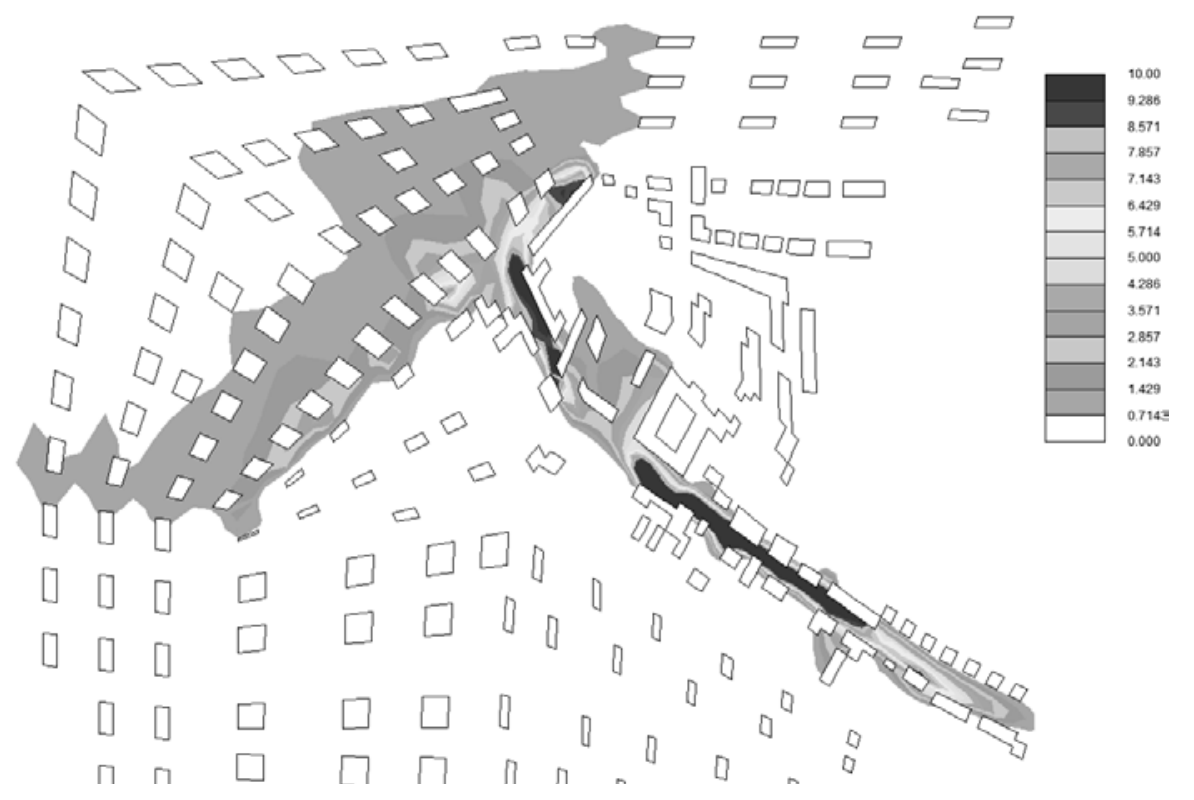

Figure 7: Calculated concentration field of specific emissions for southeast wind of $2 \mathrm{~m} / \mathrm{s}$.

\section{PRODUCTION OF CONCENTRATION FIELD DATABASE}

The concentration fields were formed into a database of concentration maps, so that the calculated concentration fields would not stay only as a content of continuous reports. This database can be a tool for a quick orientation in results and a practical tool for the evaluation of similar areas.

The database is an interactive tool allowing a quick search for corresponding situations and displaying of reached results, which can help the future users to evaluate the imission burden of similar settlements. Taking into account the fact that in the close vicinity of emission sources and in urban areas "under building roofs" it is impossible to use common recommended dispersion models, the database represents the only option to quickly evaluate local areas along roads while considering the specific geometry of buildings and traffic characteristics. 
The database is inserted with the outputs of calculations which are expected for further use. Each inserted concentration field is identified with a description of the geometry of an element in question, description of corresponding meteorological conditions (wind velocity and direction), traffic parameters (driving speed, traffic volume), basic average emission level of vehicles, and background concentration.

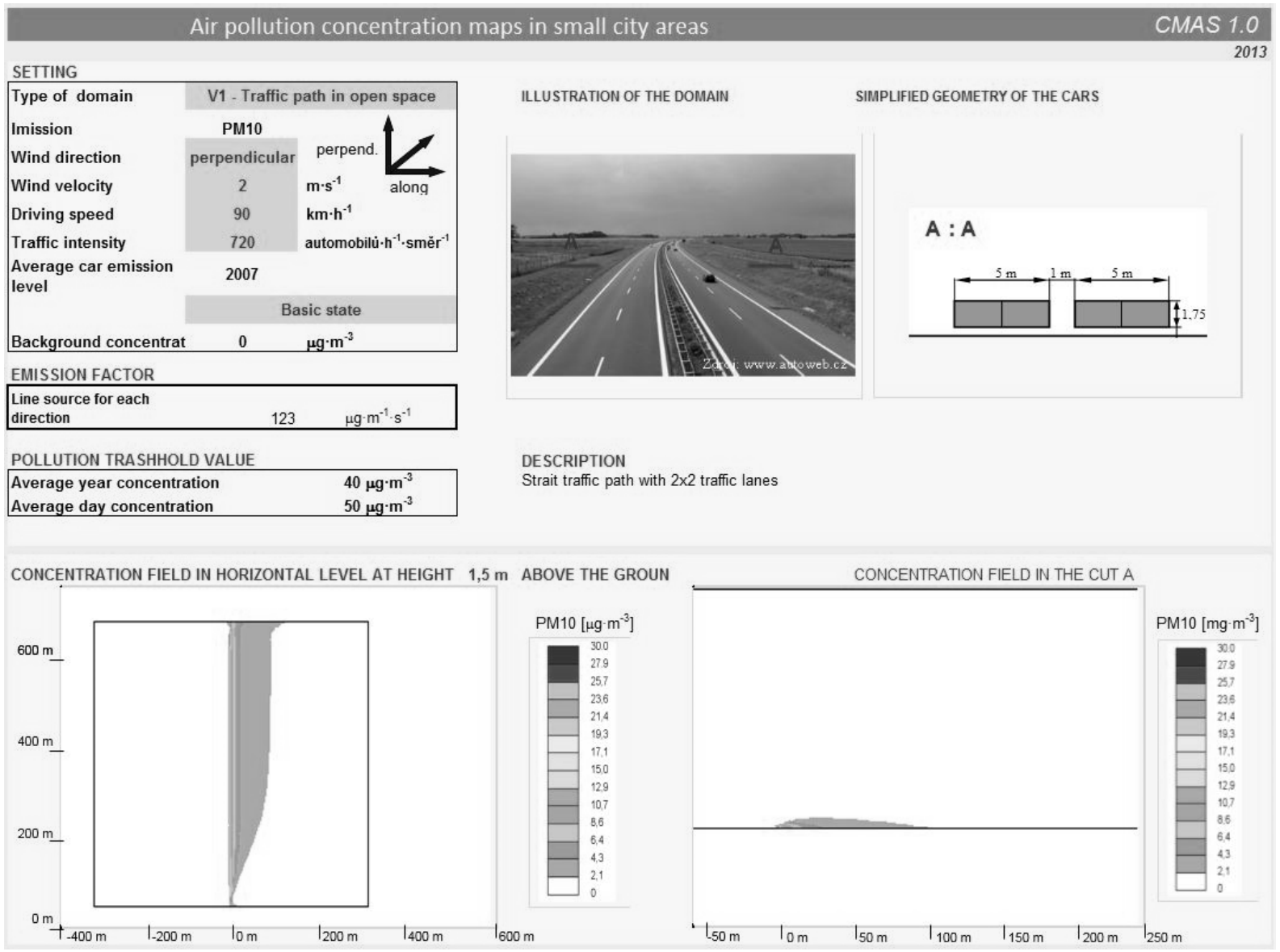

Figure 8: Example of graphic interface of concentration map database.

The pull-down menus are used for selecting specific parameters. The menus are used for displaying the existing offer of parameters for which results are available in the database. In the current version of the database, the pull-down menus are available for all values of quantities with a background tinge of brick colour.

\section{ACKNOWLEDGMENT}

This work was produced within an R\&D project "Quantification of air pollution and the resulting health risks in small settlements of Czech Republic and system solutions" No. TA02021267, funded by the Technological Agency of the Czech Republic.

The results which are published here are the outcome of a cooperation of Centrum dopravního výzkumu, v.v.i. (Transport Research Centre), ENVItech Bohemia, s.r.o. and NETME Centre, regional research and development centre built by financial sources from the Operational Programme of Research and Development for Innovations within the project of NETME Centre (New Technologies for Mechanical Engineering), Reg. No.: CZ.1.05/2.1.00/01.0002, and supported in the following sustainability phase through a project 
NETME CENTRE PLUS (LO1202), financially supported by the Ministry of Education, Youth and Sports within the support of the programme "National Sustainability Programme I".

\section{REFERENCES}

Claiborn, C.S., Lamb, B., Miller, A., Beseda, J., Clode, B., Vaughan, J., Kang, L., Newvine, C., 1998. Re-gional measurements and modelling of windblown agri-cultural dust: The Columbia Plateau PM10 Program. J. Geophys. Res. 103, pp. 19753-19768.

Csanady, G.T., 1973. Turbulent Diffusion in the Environment. Reidel, Dordrecht, Holland.

Jícha, M., Pospíšil, J., Katolický, J., 2000. Dispersion of pollution in street canyon under traffic induced flow and turbulence. Environmental monitoring and assessment, 65 (1-2), pp. 343-351.

Kukkonen, J. et al., 2001. A semi-empirical model for urban PM10 concentrations, and its evaluation against data from an urban measurement network. Atmospheric Environment, 35 , pp. 4433-4442

Moussiopoulos, N. et al., 2003. Air Quality in Cities, Fi-nal Report of project SATURN: Subproject EURO-TRAC-2. Germany: Springer. ISBN 3-540-00842-X.

Pospíšil, J., Jícha, M., 2008. Behavior of Particulate Matter Produced by Cars in a regional Model of Urban Canopy Layer. Transactions on Transport Sciences, 1 (4), pp. 157-164.

Pospíšil, J., Huzlík, J., Ličbinský, R., 2014. Rozptyl znečišt'ujících látek z liniových zdrojů v malých sídlech [Dispersion of Pollutants from Line Sources in Small Municipalities]. In Jandová, V., Mikulová, I., Ličbinský, R. (eds.). VI Czech and Slovak Conference "Transport, Health and the Environment", Brno (Czech Republic), November 10-11, 2014. Brno: Transport Research Centre, pp. 31-38. ISBN 978-80-86502-85-4. (in Czech)

Punjrath, J.S., Heldman, D. R., 1972. Mechanisms of small particle re-entrainment from flat surface. Aerosol Science, 3 (6), pp. 429-440.

Saho, Y., Lu, H., 2003. A simple expression for wind erosion treshold friction velocity. Journal of Geophysi-cal Research 1005 (D17), 22, pp. 437-443.

NOTICE: The article was taken over from the proceedings of VI Czech and Slovak Conference "Transport, Health and the Environment" held on 10 - 11 November 2014 in Brno (Czech Republic), upon the decision of the proceedings publisher Transport Research Centre and with the consent of the authors of the article.

With the consent of the authors, the article was adapted on the basis of editing instructions of Transactions on Transport Sciences journal and translated into English language. 